AperTO - Archivio Istituzionale Open Access dell'Università di Torino

Biological and ecological data on an established rainbow trout (Oncorhynchus mykiss) population in an Italian stream

This is a pre print version of the following article:

Original Citation:

Availability:

This version is available http://hdl.handle.net/2318/1728424

since 2020-02-19T09:32:02Z

Published version:

DOI:10.1127/1863-9135/2011/0179-0067

Terms of use:

Open Access

Anyone can freely access the full text of works made available as "Open Access". Works made available under a Creative Commons license can be used according to the terms and conditions of said license. Use of all other works requires consent of the right holder (author or publisher) if not exempted from copyright protection by the applicable law. 


\section{Biological and ecological data on an established rainbow trout (Oncorhynchus mykiss) population in an Italian stream}

Alessandro Candiotto ${ }^{1}$, Tiziano Bo $^{2}$, Stefano Fenoglio ${ }^{2}$

${ }^{1}$ Via Della Grava 5, 15077 Predosa (AL), Italy.

${ }^{2}$ Dipartimento di Scienze dell'Ambiente e della Vita, Università del Piemonte Orientale, Via Teresa Michel 11, 15121, Alessandria, Italy

Corresponding author:

Stefano Fenoglio, Dipartimento di Scienze dell'Ambiente e della Vita, Università del Piemonte Orientale, Via T. Michel 11, 15121, Alessandria, Italy tel: +30 0131 360201, fax: +390131360243 e.mail:fenoglio@unipmn.it 


\begin{abstract}
The rainbow trout Oncorhynchus mykiss (Walbaum, 1792) is probably the most widely introduced fish species in the world, but interestingly few populations have acclimated and reproduced outside the native area. This work provides biological and ecological data on one rare European self-sustaining population through three-years of data collection in the Lemme Creek (Northern Apennines, Italy). Regular reproductive events were recorded and analysed: gonad maturation, the presence of nests, juveniles and the rearing of alevins from naturally hatched eggs confirmed that the reproductive period is in the first months of the year. Biometric and population parameters are comparable to values recorded for the species, with a density of $0.60 \pm 0.21$ individuals $/ \mathrm{m}^{2}$, a biomass of $5.18 \pm 2.75 \mathrm{~g} / \mathrm{m}^{2}$ and a weight/length relationship $\mathrm{W}=5 \mathrm{E}-05 \mathrm{~L}^{2.69}$. We also provide the first data on the diet of an acclimated European rainbow trout population (most studies regard hatchery-reared rainbow trout): gut content analysis revealed a high trophic spectrum, with evident seasonal differences. We suggest that interactions among several factors played a main role in the invasion and recruitment success. The lack of reproductive capacity has long been considered an interesting asset of this sport-fishing species, so that introductions of rainbow trout in European waters have been encouraged for many years and intentional releases still occur. Our study demonstrated that, in some cases, $O$. mykiss can constitute self-sustaining, stable populations, able to survive over a long time period and to colonise areas that naturally lack other salmonids. The ability to create naturally reproducing populations may represent a local threat to the rich biological diversity of the area.
\end{abstract}

Keywords: Oncorhynchus mykiss, European self-sustaining population, exotic salmonid, rainbow trout, Apennines 


\section{Introduction}

The rainbow trout Oncorhynchus mykiss (Walbaum, 1792) is probably the most widely introduced fish species in the world. This salmonid is native to tributaries of the Pacific Ocean in Asia and North America (mainly west of the Rocky Mountains from northwest Mexico to the Kuskokwim River, Alaska) (Jonsson et al. 1993). This species has been introduced worldwide for sport fishing and commercial aquaculture; it is present in all temperate and sub-Arctic regions of the world (except Antarctica) and in localities above $1200 \mathrm{~m}$ a.s.l. in tropical areas (Fausch 2008; Froese \& Pauly 2009).

Ecologically, O. mykiss is a very flexible organism, preferring fresh and well-oxygenated waters with a temperature of around $12{ }^{\circ} \mathrm{C}$, but also tolerating a wide thermal range, from 5 ${ }^{\circ} \mathrm{C}$ to $24{ }^{\circ} \mathrm{C}$ (Froese \& Pauly 2009). In its native area, O. mykiss shows great reproductive plasticity: the incidence of anadromy is highly variable between populations and among individuals within populations, and there are also varying degrees of parity across populations, ranging from highly reduced iteroparity to high iteroparity (Willson 1997). Natural O. mykiss populations can be monomorphic, composed exclusively of anadromous (also called Steelhead) or non-anadromous individuals (called resident rainbow trout), or polymorphic, composed of both anadromous and non-anadromous individuals (Narum et al. 2004). Sympatric populations of Steelhead and resident rainbow trout may occasionally interbreed (Leider et al. 1995), and some authors have hypothesized that anadromous and non-anadromous life histories of $O$. mykiss represent alternative phenotypic options rather than distinct evolutionary types (McCusker et al. 2000; Brannon et al. 2004). However, other authors have observed that interbreeding between Steelheads and resident rainbow trout is quite uncommon (Zimmerman \& Reeves 2000). This apparent reproductive isolation is probably due more to segregation in the timing and location of spawning between forms than to genetic incompatibility (Zimmerman \& Reeves 2002). Otolith microchemistry (in particular comparison of the $\mathrm{Sr}$ :Ca ratios) was used to determine the maternal origin of trout, showing that Steelhead and resident rainbow trout juveniles were not equally distributed among rearing habitats (Zimmerman \& Reeves 2002; Zimmerman et al. 2009).

This salmonid is a quite opportunistic predator, with a wide trophic spectrum. Aquatic invertebrates are usually one of the most common prey found in rainbow trout stomachs: Diptera, Trichoptera and Ephemeroptera are among the preferred items but trout generally feed on the most available taxon (Dedual \& Collier 1995). Most invertebrates are collected in the drift, but $O$. mykiss also preys among the elements of the substrate, e.g. ingesting large 
Diptera and cased caddisflies (Angradi \& Griffith 1990). Other evidence of great trophic plasticity is that shifts in feeding mode (drift versus benthic) are usually reported in cases of cohabitation with other salmonids, such as Chinook salmon (Oncorhynchus tshawytscha), to reduce interspecific competitive interactions (Johnson 2007). Terrestrial organisms present in the drift are also usually ingested; in small forested headwater streams, this food type can be of great importance, representing up to $70 \%$ of the total energy input of this species (Nakano et al. 1999). The importance of fishes and other vertebrates in the O. mykiss diet varies with the size of the salmonid, with the frequency of piscivory generally increasing with body size, habitat and fish community: different strains of $O$. mykiss can show different levels of piscivory, also depending on the amount of fish prey available (Pusey \& Morrison 1989; Hubert et al. 1994). Trophic opportunism leads O. mykiss to feed on large Decapoda when available and abundant, e.g. the Marron (Cherax cainii) in Western Australia (Tay et al. 2007). Some studies showed that predation is discontinuous through the day, with different peaks depending on local conditions, and that it apparently did not occur after twilight (Angradi \& Griffith 1990).

Oncorhynchus mykiss has been widely introduced throughout the world, and there seem to be few limiting factors to its distribution. Indeed, it has successfully adapted to a wide variety of new habitats, such as streams, rivers, lakes, ponds, and artificial impoundments. However, successful spawning in European rivers is rare and populations are exclusively sustained by continuous releases and escapes from hatcheries and farms. Some cases of naturally reproducing populations are known from northern Europe, and in particular from Norway (Gammelsaeter \& Dǿnnum 1994; Hindar et al. 1996; Saegrov et al. 1996), Sweden (Svärdson \& Nilsson 1985; Lindahl 1985; Landergren 1999), Denmark (Frier et al. 1995) and Finland (Saura et al. 2002; Korsu \& Huusko 2010). Self-reproducing populations are not known for most other European countries, with the exception of very few localities such as some Slovenian rivers (Vincenzi et al. 2010). Introduced in Europe around 1880, O. mykiss appeared in Italy a few years later: Bruno (1987) reported that between 1891 and 1892 some individuals were imported from California and released in Albano Lake. Since then, the growing economic interest in this salmonid has led to a massive diffusion in the entire inland water system of the peninsula (Gandolfi et al. 1991).

The aim of this study was to acquire information about the biology of one of the rare European spawning populations of O. mykiss, especially on its reproductive biology, biometry, population density and trophic habits. We also provide some explanations of the 
successful reproduction of this particular population and speculate on its potential impact on the native fauna.

\section{Materials and methods}

\section{Study area}

The study was conducted in the Lemme Creek, a small tributary of the Orba River, NW Italy (44 35' 45', $8^{\circ} 51^{\prime} 41^{\prime}$ '; altitude $430 \mathrm{~m}$ a.s.1.). Dense woodlands, with small scattered urban areas, cover the catchment. The mean discharge of the lotic system at the study station is 800 $1 / \mathrm{s}$, with a peak in the cold season after autumn-winter rains and a baseflow in summer (Provincia di Alessandria Hydrological Service, pers. comm.). This lotic system is of good environmental quality, reaching the First Class in the Extended Biotic Index system (Ghetti 1997), corresponding to an environment without human impact (Bo et al. 2007). No native salmonids (such as brown tout, Salmo (t.) trutta L. 1758) are present, and the fish fauna is represented by Cobitis taenia L. 1758, Leuciscus cephalus (L. 1758) and Padogobius bonelli (Bonaparte 1846). The main environmental parameters are reported in Table 1. In the study period, water temperature was measured three times/week at 09:00 in the morning.

\section{Reproductive biology}

We used various techniques to determine if the Lemme rainbow trout constitute a selfsustaining reproductive population:

- analysis of Gonado-Somatic Index;

- identification of nests and laying females;

- identification of eggs and rearing of juveniles.

Temporal patterns of the reproductive cycle were investigated by analysing seasonal variation of the Gonado-Somatic Index (GSI); GSI is a calculation of gonad mass as a proportion of total body mass (GSI = [Gonad Weight / Total Tissue Weight $]$ x 100, according to Barber \& Blake 2006). In total, 70 females and 54 males were analysed. We also assessed relative fertility $(\mathrm{Nr})$ according to the formula: $\mathrm{Nr}=\mathrm{nu} / \mathrm{BW}$, where $\mathrm{nu}=$ total egg number and $\mathrm{BW}=$ total fish weight $(\mathrm{kg})$ (Nagler et al. 1999). To analyse relative fertility, we considered 28 individuals, avoiding females that had already laid or that were in an evident laying phase. To identify laying females, nests and eggs, we conducted three sampling campaigns (2000, 2001 and 2002). Rearing of juveniles was carried out in 2001 and 2002: on two occasions (7 March 2000 and 11 April 2001), small amounts of eggs (respectively 100 in 2000 and 80 in 2001) 
were removed from two nests. The eggs were placed in a meshed box set in a small tributary of the Lemme Creek. At hatching, sac fry were collected with a fine-mesh net $(500 \mu \mathrm{m})$ and taken to the laboratory where they were reared in a circular thank (diameter $1.60 \mathrm{~m}$, height $0.60 \mathrm{~m}$ ) and fed with small invertebrates and then a trout farming food containing about $40 \%$ protein and $10 \%$ fat.

\section{Population density and biometry}

Biometric and age data were collected for 794 specimens. Fish total length was measured with an ichthyometer to the nearest lower millimetre $(\mathrm{mm})$, and individual weight was measured with a top loading digital balance to an accuracy of $0.1 \mathrm{~g}$. Since fish weight varies as some power function of length (Quinn \& Deriso 1999), we calculated the coefficient of length-weight relationship according to the formula: $\mathrm{W}=\mathrm{aLb}$, where $\mathrm{W}$ ( $\mathrm{g}$ ) is the body weight, $\mathrm{L}(\mathrm{cm})$ is the total body length, $\mathrm{a}$ is a constant and $\mathrm{b}$ an exponent usually lying between 2.5 and 4.0 for an ideal fish that maintains the same shape (Bagenal \& Tesch 1978). When $b=3$, growth is isometric; when $b<3$, growth is allometric and the fish is 'lighter for its length' than an ideal fish; when $b>3$, growth is allometric and the fish is 'heavier' than an ideal fish.

Ages were determined by counting scale annuli (Sparre \& Venema 1996): this technique was chosen because it is less invasive than the study of otoliths. Scales were taken from the area between the dorsal fin and lateral line, according to Lum and Taylor (2006), then cleaned in a potassium hydroxide solution (5\%) to eliminate tissue and washed in water. Approximately 20 scales were selected from each fish, placed between glass slides, and magnified and examined with a stereomicroscope (1-60x). An 80 to $100 \%$ agreement between the ages given from reading multiple scales per specimen was considered a measure of accuracy and precision for each individual age assessment.

On six occasions during the study period, quantitative samplings were performed to assess the population density and biomass. Sections of approximately $400 \mathrm{~m}^{2}$ were electrofished 3 times for total population estimates. On all occasions, the electrofishing crew consisted of two persons: one operating the anode and the other catching the stunned fish with a dip net. Electrofishing was carried out with a backpack electric fishing machine (SCUBLA ELT60, operated at $25-100 \mathrm{~Hz}$ and $300 / 550 \mathrm{~V}$ ) and population densities were estimated by the method described in Seber and Le Cren (1967). All captured fish were measured and weighed. Biomass calculation was performed in autumn 2001. 


\section{Trophic ecology}

We collected electrofishing samples in two seasons to characterise the diet and trophic ecology of the rainbow trout population: cold season (three samplings in January-February 2001 and 2002) and summer season (three samplings in June-July 2001 and 2002). In total, 140 stomachs were collected (76 in the cold season and 64 in the summer season), preserved in $10 \%$ formalin for one week, and then placed in $70 \%$ ethanol for identification of the contents. Food items were identified to the lowest practical taxonomic level and counted.

\section{Results}

\section{Reproductive biology}

The Gonado-Somatic index values for males and females are reported in Fig. 1. The highest mean values, corresponding to maximum gonad development, were recorded in JanuaryFebruary for males and in February for females. Apparently no females laid eggs in the first half of February, while most females laid in March and very few (mostly younger females) in early April. After March, the mean GSI values decreased in both males and females, indicating that most specimens reproduce in a period comprising the end of February and all of March. The mean temperature was about $7.30^{\circ} \mathrm{C}( \pm 2.09$ SD) in this period.

Regarding relative fertility, the mean number of mature eggs was 4693 eggs $/ \mathrm{kg}$ of female weight ( $\pm 947 \mathrm{SD}$ ), with a minimum of $3297 \mathrm{eggs} / \mathrm{kg}$ and a maximum of $6888 \mathrm{eggs} / \mathrm{kg}$. Larger laying females measured $279 \mathrm{~mm}$, with a weight of $235 \mathrm{~g}$ and an approximate age of 34 months, while smaller laying females measured $150 \mathrm{~mm}$, with a weight of $34 \mathrm{~g}$ and an estimated age of 22 months. Mature eggs had a mean diameter of $4.3 \mathrm{~mm}( \pm 0.2 \mathrm{SD})$.

During the study years (2000-2002), no nests were found in January and February 2000. The first nest was detected on 7 March 2000. Twenty nests were found in March 2000 and another 30 in March-April 2001, mostly in shallow gravel sediments. The mean length of nests was $40.5 \mathrm{~cm}( \pm 4.2 \mathrm{SD})$, mean width $34.2 \mathrm{~cm}( \pm 2.9 \mathrm{SD})$, mean depth $23.3( \pm 2.9 \mathrm{SD})$, mean water current velocity $0.20 \mathrm{~m} / \mathrm{s}( \pm 0.01 \mathrm{SD})$ and mean water temperature $7.90{ }^{\circ} \mathrm{C}( \pm 3.15 \mathrm{SD})$.

In March 2000, five females who had just spawned were captured in the area near the nests: they had a mean length of $261.4 \mathrm{~mm}( \pm 14.3 \mathrm{SD})$ and a mean weight of $196.0( \pm 43.3 \mathrm{SD})$.

Egg development required approximately 329 degree-days (31 days with a daily mean temperature of $10.6{ }^{\circ} \mathrm{C}$ ). The rearing of sac fry confirmed that the eggs belonged to rainbow trout. In laboratory conditions, with a mean temperature of $15.0^{\circ} \mathrm{C}$, young reached a length of $50.0 \mathrm{~mm}$ in 36 days. Moreover, in both years (on 25 April 2000 and 5 May 2001), many 
rainbow trout fry that had naturally hatched in the stream were collected with a $250 \mu \mathrm{m}$ mesh net.

\section{Population density and biometry}

The natural density in the study site was $0.60 \pm 0.21$ individuals $/ \mathrm{m}^{2}$, with a biomass in autumn 2001 of $5.18 \pm 2.75 \mathrm{~g} / \mathrm{m}^{2}$. The number of specimens per age class was calculated on the same occasion. Age classes density data was: $0+=0.451,1+=0.095,2+=0.050,3+=0.012,4+=$ 0.003. The weight/length (W/L) relationship equation calculated for the Lemme trout population $(n=794)$ during the sampling period was: $\mathrm{W}=5 \mathrm{E}-05 \mathrm{~L}^{2.69}\left(\mathrm{r}^{2}=0.98-\right.$ Fig. 2$)$. The mean weights and lengths for each age class are reported in Table 2.

\section{Trophic ecology}

We examined the gut contents of 140 O. mykiss from the study area. Trout were collected by electrofishing in two different seasons. The mean length was $199 \mathrm{~mm} \pm 76$ (minimum $87 \mathrm{~mm}$, maximum $390 \mathrm{~mm}$ ). The age ranged from 1 to 4 years. We detected a total of 9928 ingested organisms; in some specimens, we also detected other items, such as 25 small feathers, 5 small seeds, some gravel, sand and parts of filamentous algae. $96.4 \%$ of guts contained animal remains and only five (3.6\%) were completely empty. In the cold season (February-March), feeding activity was mostly based on aquatic invertebrates: larvae of Diptera Chironomidae were the most ingested item (71.0\% of total ingested invertebrates), followed by immature Plecoptera (12.2\%), immature Ephemeroptera (3.9\%) and larvae of Trichoptera (2.84\%). In the June and July samplings, terrestrial (riparian) and flying insects were the most important prey of this $O$. mykiss population: in this period, flying insects (adult midges, stoneflies, mayflies and others) constituted $47.9 \%$ and Formicidae $23.0 \%$ of ingested prey (Fig. 3). Only one gut contained fish remains: two small rainbow trout were found in the stomach of a 244 $\mathrm{mm}$ length specimen. The same specimen also ingested a freshwater crayfish (Austropotamobius pallipes). In summer, we also found a few reptiles in the guts (an undetermined juvenile of Natrix sp., remains of Podarcis muralis and Anguis fragilis).

\section{Discussion}

The main result of our study was that the rainbow trout in the Lemme Creek constitute a selfsustaining population, with regular reproductive events concerning many individuals. The number of individuals with evident gonad maturation, the amount of nests and the presence of alevins and juveniles were obvious signs of reproductive capacity. The reproductive period 
was in the first months of the year, with maximum gonad development in January-February for males and in February for females. Nest creation and reproductive activity peaked in March: nest characteristics (dimensions, water depth and velocity), relative fertility (number of eggs $/ \mathrm{kg}$ ) and mature egg size were in the range of values reported in other studies of populations in their native area (Stefferud 1993; Muhlfeld 2002; Bromage et al. 1992). Hatching occurred mostly in the second and third week of April. Fry were present in the stream from late April and May. The population density and age class distribution were typical of well-structured populations, with a hierarchical reduction of the number of individuals in the different cohorts. The weight/length relationship was comparable to that reported in other studies (Naemm et al. 2000). In particular, our b value fell in the range of values found for rainbow trout, that is $b=2.59-3.34$ (Carlander 1969), indicating allometric growth for this population. Most studies on the condition of rainbow trout in their native area have presumed a general isometric growth (Knapp \& Dudley 1990; Gipson \& Hubert 1991). In our population, the low $\mathrm{b}$ value was probably associated with sub-optimal conditions of both the habitat (small lotic system) and trophic availability (mostly insectivorous diet). Apart from these considerations, we believe that relatively high water temperatures in the Apennine area may play an important role in determining growth patterns; in fact, some studies have reported that rainbow trout subjected to elevated water temperatures exhibit high metabolic demands, which can lead to growth suppression (Hokanson et al. 1977; Brett 1979).

Data on the diet of acclimated European rainbow trout populations are extremely scarce, since most studies have dealt with "put-and-take", recreational introduced fish; it is likely that in such hatchery-reared trout the evolution and formation of the diet is partly unnatural (Delmastro 1981; Metcalf et al. 1997). The diet of the Lemme Creek rainbow trout showed a wide trophic spectrum and high ecological plasticity: the trout fed on benthic, drifting and floating invertebrates. In cold months, aquatic invertebrates were the most important food source, while in summer most prey came from terrestrial habitats. Flying insects, ants and other riparian invertebrates entered the diet in this period. Small reptiles, fishes and decapods were also occasionally consumed.

Interestingly, most rainbow trout populations outside the native area are not self-sustaining, and successful reproduction in Europe is rare (Landergren 1999; Fausch 2007). The lack of reproductive capacity has long been considered an interesting asset of the species, as it prevents hybridization with local salmonids and excessive diffusion. Hence, introductions of rainbow trout in European waters have been encouraged for many years and intentional releases still occur for sport fishing (Rabitschl \& Essl 2006). For this reason, our description 
of some biological and ecological characteristics of one of the rare self-sustaining European populations is of great interest.

We believe that this population has maintained reproductive capacity because of a series of contributing factors:

a) First of all, rainbow trout show naturally high heterogeneity of reproductive traits (Willson 1997; Narum et al. 2004) and artificial breeding has created new breeds: for example, although this species is a spring spawner, artificial propagation has emphasized the development of fall spawners, thus enabling hatcheries to produce size-specific rainbow trout year round (Behnke 2002). This extreme variability of reproductive characteristics may lead to a virtual reproductive impossibility in populations created by numerous, more or less recent introductions. In our case study, the Lemme population was introduced in the 1930s (Provincia di Alessandria Fishing Service, pers. comm.) and the original nucleus probably consisted of only a few individuals, helping to maintain a homogeneous pool of reproductive traits.

b) Another very interesting factor is that environmental conditions seem to have been excellent for rainbow trout reproduction. Lemme Creek is one of the few rivers in the Northern Apennines that has not suffered as a result of hydrological and chemical alterations: large parts of the riverbed had substrates in the range of suitable spawning areas $(3-100 \mathrm{~mm}$; Raleigh et al. 1984); furthermore, there was high environmental heterogeneity, with many important components for trout reproduction and life, such as large woody debris, boulders and undercut banks (Bjornn \& Reiser 1991).

c) The local flow regime has probably played a major role: as pointed out by Fausch et al. (2001), flow regimes are extremely important in determining the success of $O$. mykiss reproductive events. Discharge peaks in Northern Apennine streams are produced by autumnwinter rains, after which flows decline to baseflow in early summer. These flow conditions (winter flooding and low summer flows) are considered the most appropriate for rainbow trout reproduction (Raleigh et al. 1984).

d) Water temperatures in the reproductive period are another key element. The optimum temperature for incubation of rainbow trout eggs is among the highest for salmonids (Kwain 1975). Hence, low water temperatures may be the reason for the unsuccessful invasions of many European lotic systems, such as the relatively nearby Alpine streams (where mean temperatures in February are in the range of $2-4{ }^{\circ} \mathrm{C}$ ). In the Lemme Creek, water temperatures in January-February were generally moderate and in the optimal mean range for rainbow trout reproduction (Behnke 2002; Bernstein \& Montgomery 2008). 
e) In a recent study Ciereszko et al. (2010) reported that, while spermatozoa of many Salmonidae can be motile in a wide range of $\mathrm{pH}$ values, rainbow trout spermatozoa exhibit no motility at $\mathrm{pH} 7.0$ and below. The high $\mathrm{pH}$ values of the Lemme creek could represent another important factor explaining the establishment of the studied rainbow trout population. f) Some investigators believe that rainbow trout invasion in Europe is limited by competition with the native brown trout (Gatz et al. 1987; Hindar et al. 1996). In this regard, Lemme Creek has been a suitable environment for the establishment of a self-sustaining $O$. mykiss population because the brown trout has been naturally lacking in this and other Northern Apennine lotic systems (Gandolfi et al. 1991), so that intraspecific competition is nil. Interactions among these different factors (characteristics of the donor population, flow regimes, water winter-spring temperatures, habitat characteristics and lack of native trout) likely explain why rainbow trout can successfully reproduce in the Lemme Creek.

\section{Concluding remarks}

Freshwater ecosystems are among the most endangered and invaded environments (Bampfylde et al. 2010), and invasive species are a major contributor to biodiversity loss in streams and rivers (Dextrase \& Mandrak 2006). Introduced fishes can affect local biota and ecological systems in many ways, for example they can prey upon, hybridize with and outcompete autochthonous species and transfer pathogens and diseases (Roll et al. 2007). In an IUCN report on biological invasions, $O$. mykiss was included among the world's 100 worst invasive alien species (Lowe et al. 2004), and recent studies have reported that this species affects not only the biological but also functional integrity of invaded lotic systems (Buria et al. 2007; 2010). Our study demonstrates that, in some cases, O. mykiss can constitute selfsustaining populations able to survive over a long time period and to colonise areas that naturally lack other salmonids. This may represent a threat to local biological diversity because most Apennine low-order lotic systems naturally lack large vertebrate predators. This potential threat may be greater in a changing environment, for example in a global warming scenario. There is ample evidence that climatic warming influences the distribution of organisms (Stachowicz et al. 2002), and many studies assume the existence of a direct relationship between climate change and biological invasions (Dukes \& Mooney 1999; Thomas \& Lennon 1999). Furthermore, global climate change disrupts community structure and increases the loss and extinction of native species, whereas invasive species are more likely to be generalists than specialists and thus might be more able to adapt to new climates (Dukes \& Mooney 1999). Clark et al. (2001) analysed the effects of climate change on 
rainbow trout populations in southern Appalachian streams. Analysing different scenarios and utilising individual-based models and geographic information systems, they predicted that the increase of water temperatures resulted in increased abundances of rainbow trout. Warmer spring temperatures increased the development rates of eggs, which, with constant mortality rates, resulted in increased survival, so that the number of spawners and the annual egg production increased in a global warming scenario. In a recent review, Fenoglio et al. (2010a) reported that the effects of global climate change could be very important in Italian freshwater systems. Therefore, we can hypothesize that autochthonous salmonids (such as Salmo trutta) may experience strong habitat reduction to the benefit of species such as invasive rainbow trout. Indeed, rainbow trout invasions have been reported to cause declines in native fishes and other aquatic biota in New Zealand, Australia, South Africa, Sri Lanka, South America, Switzerland, Japan and the United States (see Fausch 2007).

The engraftment and expansion of self-reproducing populations in low-altitude mountainous streams of the Northern Apennines may constitute a dangerous threat to the remarkable local biota. In fact, this area, situated between the Alps and the Mediterranean, is an rich biodiversity hotspot, characterised by rare and localised invertebrate taxa (Bo et al. 2009), such as Besdolus ravizzarum (Fenoglio et al. 2010b), Nemoura hesperiae (Tierno de Figueroa et al. 2009), Potamanthus luteus (Fenoglio et al. 2008), which may be threatened by the acclimation and expansion of trout populations. Since naturalized $O$. mykiss can prey on small amphibians and reptiles (Bernini et al. 2006), the expansion of this population in the area might represent a serious threat to the survival of a rare endemic salamander, Salamandrina terdigitata (Lacépède, 1788). For these reasons, further rainbow trout introductions should not be contemplated in any southern European water bodies.

Acknowledgments We would like to thank F. Bernini, G. Forneris, P.A. Nardi, M. Pascale, E. Razzetti and S. Rossi for help with field work and comments on earlier versions of this manuscript. We also thank P. Christie for the English revision. This work was supported by Provincia di Alessandria and Fondazione Cassa di Risparmio di Alessandria grants.

\section{Reference list}

Angradi, T. R. \& Griffith, J. S., 1990: Diel feeding chronology and diet selection of Rainbow Trout (Oncorhynchus mykiss) in the Henry's Fork of the Snake River, Idaho. - Can. J. Fish. Aquat. Sci. 47: 199-209. 
Bagenal, T. B. \& Tesch, F. W., 1978: Age and growth. - In: Bagenal, T. B. (ed.): Methods for the Assessment of Fish Production in Fresh Waters, 3rd edn. - Blackwell Scientific Publications, Oxford, pp. 101-130.

Bampfylde, C. J., Peters, J. A. \& Bobeldyk, A. M., 2010: A literature analysis of freshwater invasive species research: are empiricists, theoreticians, and economists working together? - Biol. Inv. 12: 1207-1219.

Barber, B. J. \& Blake, N. J., 2006: Developments in aquaculture and fisheries science, scallops: biology, ecology and aquaculture. - In: Shumway, S. E. \& Parsons, G. J. (eds.): Reproductive physiology. - Elsevier, Amsterdam, pp. 357-416.

Behnke, R. J., 2002: Trout and salmon of North America. - The Free Press, Simon and Schuster Inc., New York.

Bernstein, Y. \& Montgomery, W. L., 2008: Rainbow Trout (Oncorhynchus mykiss; Walbaum, 1792): a technical conservation assessment. - USDA Forest Service, Rocky Mountain Region.

Bernini, F., Candiotto, A., Nardi, P. A., Rossi, S. \& Razzetti, E., 2006: Reptiles in the diet of a Oncorhynchus mykiss (Osteichthyes: Salmonidae) naturalized population in Piedmont (N Italy). - Acta Herpetol. 1: 61-63.

Bo, T., Fenoglio, S., Malacarne, G., Pessino, M. \& Sgariboldi, F., 2007: Effects of clogging on stream macroinvertebrates: an experimental approach. - Limnologica 37: 186-192.

Bo, T., Fenoglio, S., López-Rodríguez, M. J. \& Tierno de Figueroa, J. M., 2009: Phenology of adult Stoneflies (Plecoptera) of the Curone stream (Northern Apennines, Italy). - J. Freshwat. Ecol. 24: 279-283.

Bjorn, T. C. \& Reiser, D. W., 1991: Habitat requirements of salmonids in streams. - In: Meehan, W. R. (ed.) - Influences of forest and rangeland management on salmonid fishes and their habitat. - American Fisheries Society Special Publication, Bethesda, pp. 83-138.

Brannon, E. L., Powell, M. S., Quinn, T. P. \& Talbot, A., 2004: Population structure of Columbia River basin chinook salmon and steelhead trout. - Rev. Fisheries Science 12: 99-232.

Brett, J. R., 1979: Environmental factors and growth. - In: Hoar, W. S., Randall, D. J. \& Brett, J. R. (eds.). - Fish physiology, Vol. VIII. Bioenergetics and growth. - Academic Press, New York. pp. 599-675.

Bromage, J. J., Randall, C., Thrush, M., Davies, B., Springate, J., Duston, J. \& Barker, G., 1992: Broodstock management, fecundity, egg quality and the timing of egg production in the rainbow trout (Oncorhynchus mykiss). - Aquaculture 100: 14-166.

Bruno, S., 1987: Pesci e crostacei d'acqua dolce d'Italia. Giunti, Firenze.

Buria, L., Albariño, R., Villanueva, V. D., Modenutti, B. \& Balseiro, E., 2007: Impact of exotic rainbow trout on the benthic macroinvertebrate community from AndeanPatagonian headwater streams. - Fund. Appl. Limnol. 168: 145-154.

Buria, L., Albariño, R., Villanueva, V. D., Modenutti, B. \& Balseiro, E., 2010: Does predation by the introduced rainbow trout cascade down to detritus and algae in a forested small stream in Patagonia? - Hydrobiologia 651:161-172.

Ciereszko, A., Dietrich, G. J., Dietrich, M. A., Nynca, J., Kuźmiński, H., Dobosz, S. \& Grudniewska, J., 2010: Effects of pH on sperm motility in several Salmoniformes species: Oncorhynchus mykiss, Salvelinus fontinalis, Salmo trutta, Salmo salar and Thymallus thymallus. J. Appl. Ichthyol. 26: 665-667.

Clark, M. E., Rose, K. A., Levine D. A. \& Hargrove, W. W., 2001: Predicting climate change effects on appalachian trout: combining GIS and individual-based modelling. - Ecol. Appl. 11: 161-178. 
Dedual, M. \& Collier, K. J., 1995: Aspects of juvenile Rainbow trout (Oncorhynchus mykiss) diet in relation to food supply during summer in the lower Tongariro River, New Zealand. - N. Z. J. Mar. Freshwater. Res. 29: 381-391.

Delmastro, G. B., 1981: Contributo allo studio dell'alimentazione di Salmo gairdneri Rich. (Osteichthyes, Salmonidae). - Riv. Piem. St. Nat. 2: 71-78.

Dextrase, A. J. \& Mandrak, N. E., 2006: Impacts of alien invasive species on freshwater fauna at risk in Canada. - Biol. Invasions. 8: 13-24.

Dukes, J. S. \& Mooney, H. A., 1999: Does global change increase the success of biological invaders? TREE 14:135-139.

Fausch, H. D., Taniguchi, Y., Nakano, S., Grossman, G. D. \& Townsend, C. R., 2001: Flood disturbance regimes influence rainbow trout invasion success among five holarctic regions. - Ecol. Appl. 11: 1438-1455.

Fausch, G. D., 2007: Introduction, establishment and effects of non-native salmonids: considering the risk of rainbow trout invasion in the United Kingdom. J. Fish Biol. 71: 132.

Fausch, K. D., 2008: A paradox of trout invasions in North America. - Biol. Invasions 10: 685-701.

Fenoglio, S., Bo, T., Tierno de Figueroa, J. M. \& Cucco, M., 2008: Nymphal growth, life cycle, and feeding habits of Potamanthus luteus (Linnaeus, 1767) (Insecta: Ephemeroptera) in the Bormida River, Northwestern Italy. - Zool. Stud. 47: 185-190.

Fenoglio, S., Bo, T., Cucco, M., Mercalli, L., Malacarne, G., 2010 a: Effects of global climate change on freshwater biota: a review with special emphasis on the Italian situation. - It. J. Zool. 77: 374-383.

Fenoglio, S., Bo, T., Lopez-Rodriguez, M. J. \& Tierno de Figueroa, J. M., 2010 b: Life cycle and nymphal feeding of Besdolus ravizzarum (Plecoptera: Perlodidae), a threatened stonefly. - Insect Science 17:149-153.

Frier, J-O., Arnason, E., Gydemo, R., Piironen, J., Hansen, L. P., Sivertsen, A., Hansen, L. P., Hesthagen, T., 1995: Threatened freshwater fish species in the Nordic countries. - Report to Nordic Council of Ministers, Copenhagen.

Froese, R. \& Pauly, D., 2009: FishBase. World Wide Web electronic publication. http:www.fishbase.org. Accessed 25 February 2010

Gammelsaeter, M. \& Dǿnnum, B.O., 1994: Varig bestand av regnbueùrret påvist i Saetervatna ved åndalsnes. - Fauna (in Norwegian) 47: 290-298.

Gandolfi, G., Zerunian, S., Torricelli, P. \& Marconato, A., 1991: I pesci delle acque interne italiane. - Ministero dell'Ambiente e Unione Zoologica Italiana. Istituto Poligrafico e Zecca dello Stato, Roma.

Gatz, A. J., Sale, M. J. \& Loar, J. M., 1987: Habitat shifts in rainbow trout: competitive influences of brown trout. - Oecologia 74: 7-19.

Ghetti, P. F., 1997: Manuale per l'applicazione dell'Indice Biotico Esteso. - Provincia Autonoma di Trento Ed., Trento.

Gipson, R. D. \& Hubert, W. A., 1991: Factors influencing the body condition of Rainbow trout in small Wyoming reservoirs. - J. Freshwat. Ecol. 6: 327-334.

Hindar, K., Fleming, I. A., Jonsson, N., Breistein, J., Szgrov, H., Karlsbakk, E., Gammelster, M. \& Donnum, B. O., 1996: Rainbow trout in Norway: occurrence, reproduction, and establishment. - NINA Oppdragsmelding 454: 1-32.

Hokanson, K. E. F., Kleiner, C. F. \& Thorslund, T. W., 1977: Effects of constant temperature and diel fluctuation on growth, mortality, and yield of juvenile Rainbow trout, Salmo gairdneri (Richarson). - J. Fish. Res. Board. Can. 34: 639-648.

Hubert, W. A., Gipson, R. D., McDowell, R. \& Stewart, A. C., 1994: Diet of Eagle Lake Rainbow Trout in Lake DeSmet, Wyoming. - N. Am. J. Fish. Manage 14: 457-459. 
Johnson, J. H., 2007: Comparative diets of subyearling Chinook Salmon (Oncorhynchus tshawytscha) and Steelhead (O. mykiss) in the Salmon River, New York. - J. Great Lakes Res. 33: 906-911.

Jonsson, N., Jonsson, B., Hansen, L. P. \& Aass, P., 1993: Coastal movement and growth of domesticated Rainbow trout (Oncorhynchus mykiss (Walbaum)) in Norway. - Ecol. Freshwat. Fish. 2: 152-159.

Knapp, R. A. \& Dudley, T. L., 1990: Growth and longevity of golden trout, Oncorhynchus aguabonita, in their native streams. - Calif. Fish. Game 76: 161-173.

Korsu, K. \& Huusko, A., 2010: Are environmental conditions in Finnish streams limiting to early life-history survival in the nonnative rainbow trout? - Fish. Sci. 76: 901-907.

Kwain, W. H., 1975: Embryonic development, early growth, and meristic variation in rainbow trout (Salmo gairdneri) exposed to combinations of light intensity and temperature. - J. Fish. Res. Board Can. 32: 397- 402.

Landergren, P., 1999: Spawning of anadromous rainbow trout, Oncorhynchus mykiss, (Walbaum): A threat to sea trout, Salmo trutta L., populations? - Fish. Res. 40: 55-63.

Leider, S. A., Phelps, S. R. \& Hullet, P. L., 1995: Genetic analysis of Washington Steelhead: implications for revision of genetic conservation management units. - Washington Department of Fish and Wildlife, Olympia.

Lindahl, K. C., 1985: Våra fiskar. Havs - och sötvattensfiskar I Norden och övriga Europa (in Swedish). - Utgiven på Nordstedts Förlag, Stockholm.

Lowe, S., Browne, M., Boudjelas, S. \& De Poorter, M., 2004: 100 of the world's worst invasive alien species a selection from the global invasive species database. - ISSG Publ., Auckland.

Lum, J. L. \& Taylor, S. G., 2006: Dolly varden and cutthroat trout migrations at Auke Creek in 2003, and abundance of cutthroat trout in Auke Lake, southeast Alaska. - Alaska Department of Fish and Game, Anchorage.

McCusker, M. R., Parkinson, E. A. \& Taylor, E. B., 2000: Mitochondrial DNA variation in Rainbow trout (Oncorhynchus mykiss) across its native range: testing biogeographical hypotheses and their relevance to conservation. - Mol. Ecol. 9: 2089-2108.

Metcalf, C., Pezold, F. \& Crump, B. G., 1997: Food habits of introduced Rainbow trout (Oncorhynchus mykiss) in the Upper Little Missouri River Drainage of Arkansas. Southwest. Nat. 42: 148-154.

Muhlfeld, C. C., 2002: Spawning characteristics of redband trout in a headwater stream in Montana. - N. Am. J. Fish. Manage. 22: 1314-1320.

Naemm, M., Salam, A. \& Bhatti, M. N., 2000: Morphometric studies on cold water fish Rainbow trout Onchorhynchus mykiss in relation to body size. - Pakistan J. Fish. 1: 55-62.

Nagler, J. J., Adams, B. A. \& Cyr, D. G., 1999: Egg production, fertility, and hatch success of american plaice held in captivity. - T. Am. Fish. Soc. 128: 727-736.

Nakano, S., Kawaguchi, Y., Taniguchi, Y., Miyasaka, H., Shibata, Y., Urabe, H. \& Kuhara, N., 1999: Selective foraging on terrestrial invertebrates by Rainbow trout in a forested headwater stream in northern Japan. - Ecol. Res. 14: 351-360.

Narum, S. R., Contor, C., Talbot, A. \& Powell, M. S., 2004: Genetic divergence of sympatric resident and anadromous forms of Oncorhynchus mykiss in the Walla Walla River, U.S.A. - J. Fish. Biol. 65: 471-488.

Pusey, B. J. \& Morrison, P. F., 1989: The diet of Rainbow trout in Wungong Dam, Western Australia. - West. Austr. Nat. 18: 37-40.

Quinn, T. J. \& Deriso, R. D., 1999: Quantitative fish dynamics. - Oxford University Press, New York .

Raleigh, R. F., Hickman, T., Solomon, R. C. \& Nelson, P. C., 1984: Habitat suitability information: Rainbow trout. - US Fish and Wildl. Serv. Washington. 
Rabitschl, W. \& Essl, F., 2006: Biological invasions in Austria: patterns and case studies. Biol. Invasions 8: 295-308.

Roll, U., Dayan, T., Simberloff, D. \& Goren, M., 2007: Characteristics of the introduced fish fauna of Israel. - Biol. Invasions 9: 813-824.

Saegrov, H., Hindar, K. \& Urdal, K., 1996: Natural reproduction of anadromous rainbow trout in Norway. - J. Fish Biol. 48: 292-294.

Saura, A., Lempinen, P. \& Leinonen, K., 2002: Vantaanjoen ja Nuijajoen koskikunnostusten Seuranta (in Finnish). - Kala-Ja Riistaraportteja, Helsinki.

Seber, G. A. F. \& Le Cren, E. D., 1967 : Estimating population parameters from catches large relative to the population. - J. Anim. Ecol. 36: 631-643.

Sparre, P. \& Venema, S. C., 1996: Introduction à l'èvaluation des stock de poissons tropicaux. - FAO, Roma.

Stachowicz, J. J., Terwin, J. R., Whitlatch, R. B. \& Osman, R. W., 2002: Linking climate change and biological invasions: Ocean warming facilitates nonindigenous species invasions. - Proc. Natl. Acad. Sci. U.S.A. 99:15497-15500.

Stefferud, J. A., 1993: Spawning season and microhabitat use by California golden trout (Oncorhynchus mykiss aguabonita) in the southern Sierra Nevada. - Calif. Fish. Game, 79: 133-144.

Svärdson, G. \& Nilsson, N. A., 1985 : Fiskebiologi. 2:a reviderade upplagan - Lts Förlag (in Swedish), Stockholm.

Tay, M. Y., Lymbery, A. J., Beatty, S. J. \& Morgan, D. L., 2007: Predation by Rainbow trout (Oncorhynchus mykiss) on a Western Australian icon: Marron (Cherax cainii). - N. Z. J. Mar. Freshwater. Res. 41: 197-204.

Tierno de Figueroa, J. M., Bo, T., López-Rodríguez, M. J. \& Fenoglio, S. 2009: Life cycle of three stonefly species (Plecoptera) from an Apenninic stream (Italy) with the description of the nymph of Nemoura hesperiae. - Ann. Soc. Entomol. Fr. 45: 339-343.

Vincenti, S., Crivelli, A. J., Jesensek, D., Rossi, G \& De Leo, G. A., 2010: Innocent until proven guilty? Stable coexistence of alien rainbow trout and native marble trout in a Slovenian stream. - Naturwissenschaften DOI 10.1007/s00114-010-0741.

Willson, M. F., 1997: Variation in salmonid life histories: patterns and perspectives. PNWRP-498. Pacific Northwest Research Station, Portland.

Zimmerman, C. E., Edwards, G. W. \& Perry, K., 2009: Maternal origin and migratory history of Steelhead and Rainbow Trout captured in rivers of the Central Valley, California. Trans. Am. Fish. Soc. 138: 280-291. 


\section{Figure legends}

Fig. 1: Males and females Gonadosomatic Index for rainbow trout of the Lemme creek (mean \pm se).

Fig. 2: Length-mass relationship of rainbow trout of the Lemme Creek

Fig. 3: Diet composition in cold and warm seasons. 


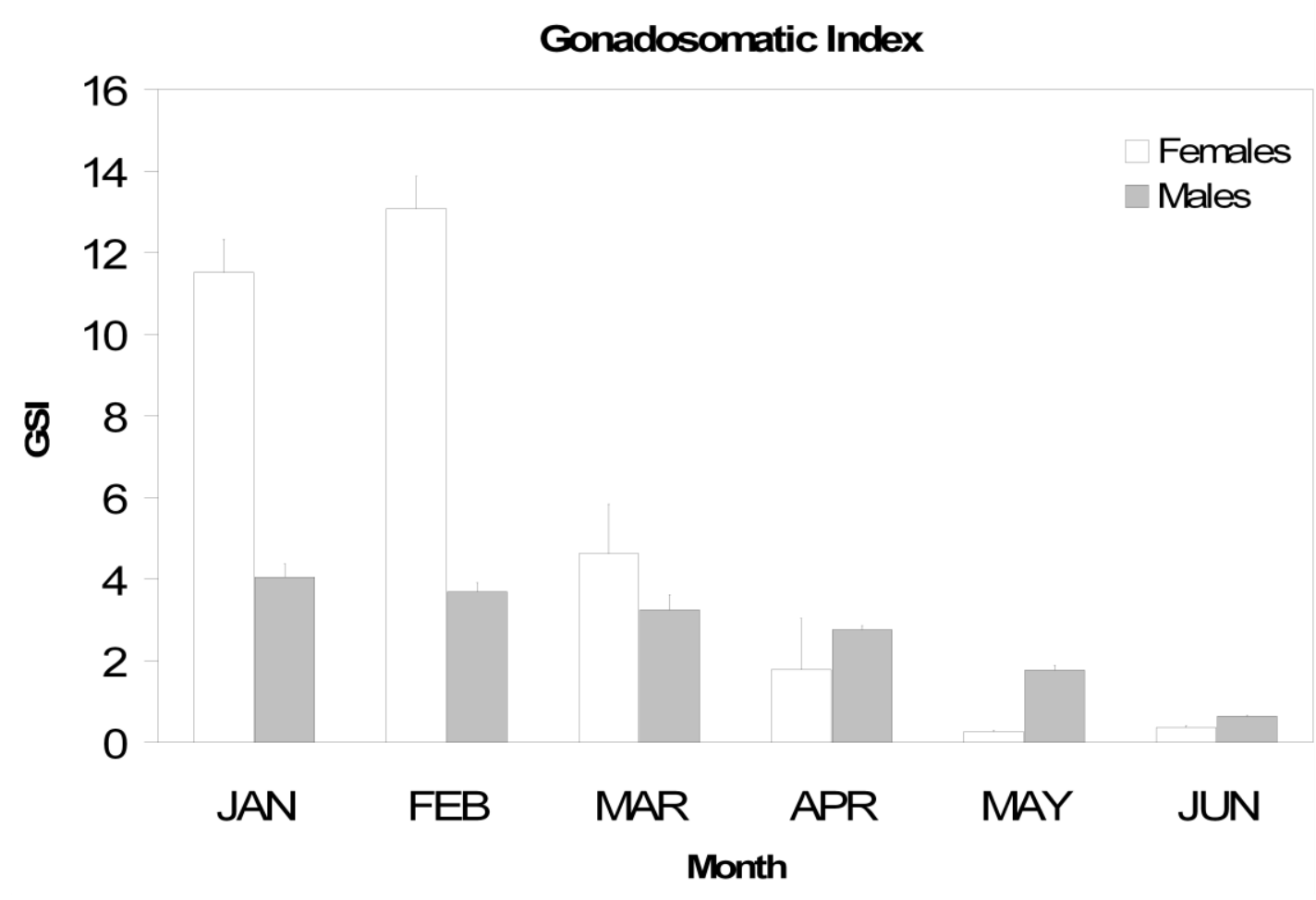

Fig. 1 


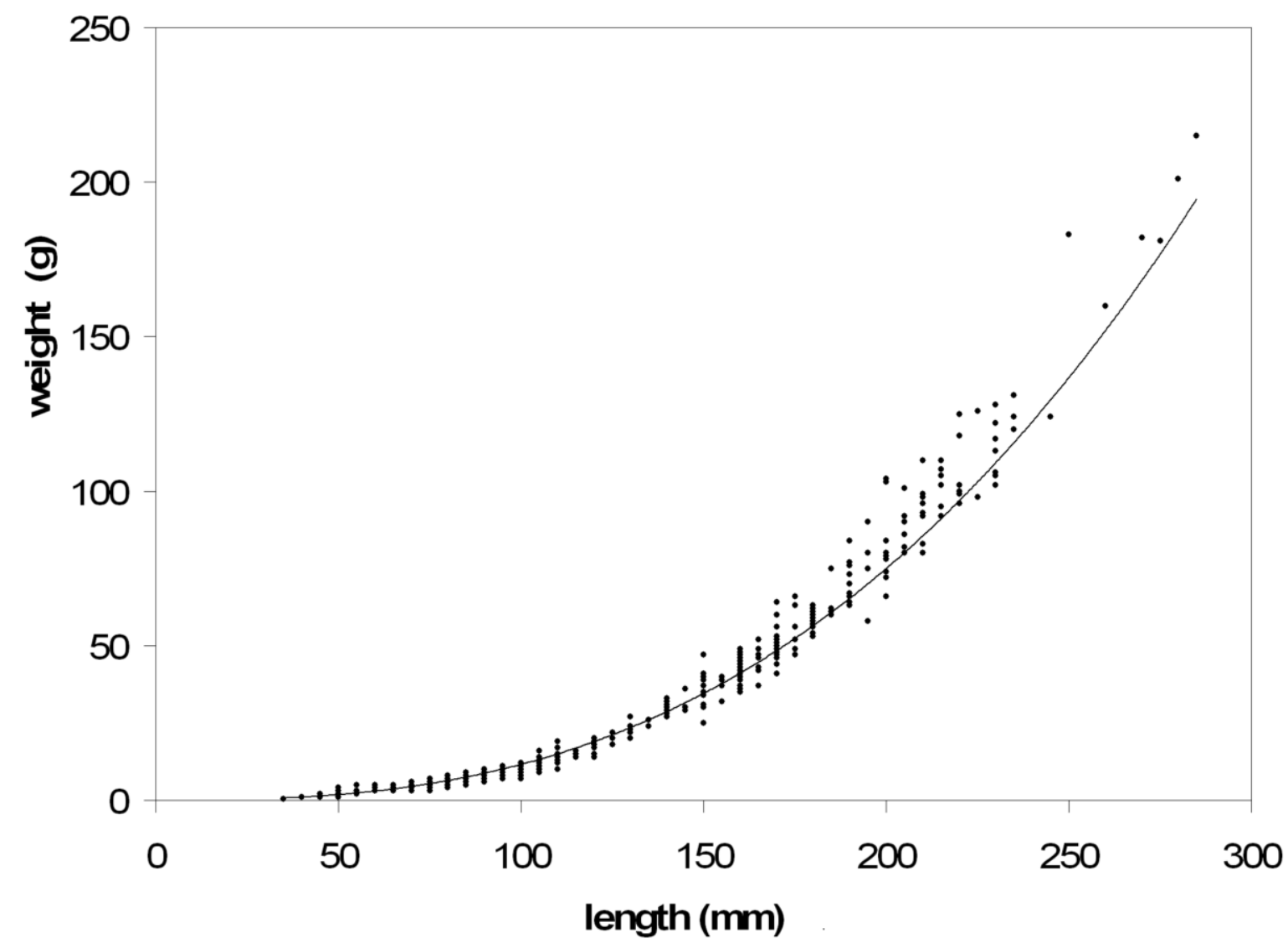

Fig. 2 


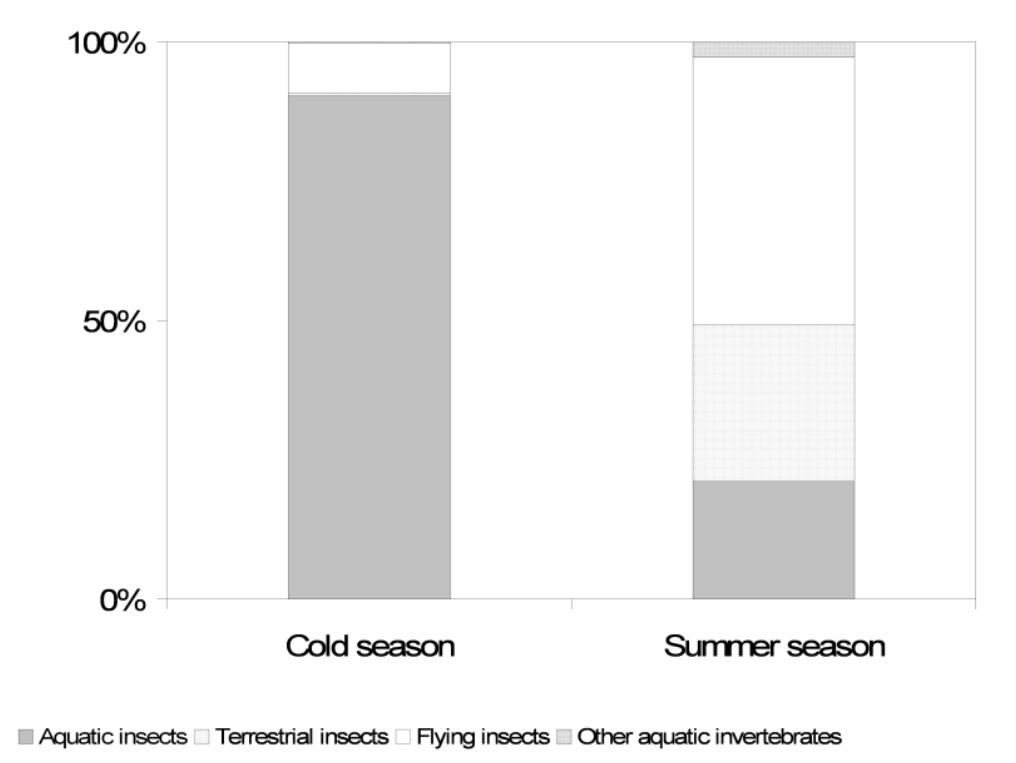

Fig. 3 


\begin{tabular}{lll}
\hline Characteristics & Mean & SD \\
\hline & & \\
Stream & & \\
Width $(\mathrm{m})$ & 3.83 & 1.05 \\
Depth $(\mathrm{cm})$ & 22.7 & 16.3 \\
Velocity $(\mathrm{m} / \mathrm{s})$ & 0.65 & 0.14 \\
Water quality & & \\
pH & 8.59 & 0.18 \\
Conductivity $(\mu \mathrm{S} / \mathrm{m})$ & 185 & 31.3 \\
Dissolved oxygen $(\mathrm{mg} / \mathrm{l})$ & 8.70 & 0.27 \\
Nitrites $(\mathrm{mg} / \mathrm{l})$ & $<0.50$ & \\
Ammonia nitrogen $(\mathrm{mg} / \mathrm{l})$ & $<0.05$ & \\
Total P $(\mathrm{mg} / \mathrm{l})$ & $<0.05$ & \\
\hline
\end{tabular}

Tab. 1: Main abiotic parameters in the study site.

\begin{tabular}{|c|c|c|c|c|c|}
\hline \multirow[b]{2}{*}{ Age classes } & \multirow[b]{2}{*}{$\mathrm{N}$} & \multicolumn{2}{|c|}{ Lenght (mm) } & \multicolumn{2}{|c|}{ Weigth (g) } \\
\hline & & mean & se & mean & se \\
\hline $0+$ & 586 & 74.0 & 1.0 & 6.14 & 0.41 \\
\hline $1+$ & 123 & 163.8 & 1.5 & 46.1 & 0.22 \\
\hline $2+$ & 65 & 199.1 & 1.9 & 81.5 & 0.21 \\
\hline $3+$ & 16 & 230.9 & 3.0 & 123.1 & 0.27 \\
\hline $4+$ & 4 & 277.5 & 3.2 & 194.7 & 0.23 \\
\hline
\end{tabular}

Tab. 2: Somatic growth (length and weight) for age classes of $O$. mykiss Lemme population. 